\title{
Upaya Fintech Syariah Mendorong Akselerasi Pertumbuhan UMKM di Indonesia
}

\author{
Saripudin $^{1 *)}$, Prameswara Samofa Nadya $^{2)}$, Muhammad Iqbal ${ }^{3)}$ \\ ${ }^{1,2,3}$ Fakultas Ekonomi dan Bisnis, Perbanas Institute \\ *Email korespondensi: iip@ perbanas.id
}

\begin{abstract}
Compared to other Islamic financial institutions, Islamic fintech has several advantages in accelerating the growth of SMEs in Indonesia. However, the existence of Islamic fintech cannot be separated from various problems. The purpose of this study is to find solutions to these problems, seen from many aspects, such as regulations, human resources, and public perceptions and the potential for fraud. The method used is qualitative with two approaches to data analysis, interactive models and SWOT analysis. The results of data analysis formulated at least three strategies. First, strengthening the ecosystem between Islamic fintech, government, academics and civil society, including sharia fintech customers and Islamic banks. Second, optimizing the potential of sharia fintech in managerial skills and sharia contract capacity. Third, the massive and targeted socialization and promotion of Islamic fintech.
\end{abstract}

Keywords: Islamic Fintech, SME enterprises, SWOT analysis, regulation, ecosystem strengthening

Saran sitasi: Saripudin., Nadya, P. S., \& Iqbal, M. (2021). Upaya Fintech Syariah Mendorong Akselerasi Pertumbuhan UMKM di Indonesia. Jurnal Ilmiah Ekonomi Islam, 7(01), 41-50. doi:http://dx.doi.org/10.29040/jiei.v7i1.1449

DOI: http://dx.doi.org/10.29040/jiei.v7i1.1449

\section{PENDAHULUAN}

Jasa keuangan dipercaya berperan penting dalam mendorong pertumbuhan ekonomi suatu negara, tetapi hal tersebut tidaklah cukup menjadi tolak ukur keberhasilan industri jasa keuangan. Menurut Demirgüç-Kunt et al. (2008) seharusnya keberadaan layanan jasa keuangan bukan hanya mendukung pertumbuhan ekonomi, tetapi juga harus mendukung terciptanya lapangan pekerjaan bagi rakyat miskin. Penciptaan lapangan pekerjaan bagi rakyat miskin dapat diwujudkan dengan mendorong pertumbuhan pada sektor Usaha Mikro, Kecil dan Menengah (UMKM). Di Indonesia, eksistensi UMKM telah terbukti dapat mengatasi berbagai permasalahan ekonomi, mulai dari mengurangi jumlah pengangguran, meningkatkan pendapatan masyarakat, mengentaskan kemiskinan, mengurangi kesenjangan distribusi pendapatan, hingga meningkatkan kesejahteraan masyarakat (Indika \& Marliza, 2019; Krisnawati, 2016; Sarfiah et al., 2019; Setiawan, 2017; Tambunan, 2012).

Kemajuan teknologi yang ditandai dengan fenomena inovasi disruptif turut mendorong tumbuhnya fintech pada industri jasa keuangan. Fintech sendiri bukan barang baru dalam industri jasa keuangan, sudah ada sejak tahun 1866 (Buckley et al., 2016). Menurut Schueffel (2016) tidak ada definisi tunggal dari fintech, tetapi ada beberapa refrensi yang dapat digunakan untuk menjelaskan tentang fintech. Menurut Leong \& Sung (2018), fintech merupakan sebuah ide inovatif dalam meningkatkan operasi layanan keuangan dengan memberikan solusi berupa teknologi yang sesuai dengan skenario bisnis. Sedangkan Maier (2016) menjelaskan bahwa fintech adalah gabungan antara keuangan dan teknologi dengan solusi yang lebih inovatif dan model bisnis yang berkelanjutan. Menurut PBI Nomor 9/12/PBI/2017 tentang Penyelenggaraan Teknologi Finansial, fintech adalah penggunaan teknologi dalam sistem keuangan yang menghasilkan produk, layanan, teknologi, dan/atau model bisnis baru serta dapat berdampak pada stabilitas moneter, stabilitas sistem keuangan, dan/atau efisiensi, kelancaran, keamanan, dan keandalan sistem pembayaran (BI, 2017).

Fintech merupakan sebuah inovasi pada industri jasa keuangan yang berpotensi untuk menjangkau 
calon debitur-debitur, khususnya sektor UMKM dan agrikultur, yang belum terjangkau oleh pelaku industri jasa keuangan eksisting (Wulandari, 2017; Zetzsche et al., 2018). Pemerintah Indonesia saat ini sedang melihat potensi dari pasar fintech di Indonesia untuk mendukung UMKM yang belum dilayani oleh industri perbankan (Minerva, 2016). Fintech syariah merupakan bagian yang tak terpisahkan dari industri fintech nasional juga berperan dalam mendorong pertumbuhan UMKM di Indonesia. Fintech syariah turut mendorong penyaluran pendanaan berbasis syariah diberbagai daerah di Indonesia yang hampir seluruh nasabahnya adalah UMKM (Prestama et al., 2019). Dengan kata lain, fintech syariah memiliki potensi dalam mendorong inklusi keuangan melalui pemenuhan kebutuhan pada segmen pasar yang nonbankable. Fintech syariah menawarkan solusi untuk UMKM dalam mengurangi kesenjangan antara lembaga keuangan dengan pihak-pihak yang membutuhkan pembiayaan proyek (Mukhlisin, 2019).

Menurut Fatwa Dewan Syariah Nasional MUI Nomor 117/DSN-MUI/II/2018, Fintech Syariah adalah penyelenggaraan layanan jasa keuangan berdasarkan prinsip syariah yang mempertemukan atau menghubungkan pemberi pembiayaan dengan penerima pembiayaan dalam rangka melakukan akad pembiayaan melalui sistem elektronik dengan menggunakan jaringan internet (DSN-MUI, 2018). Perkembangan fintech syariah di Indonesia cukup menggembirakan, menurut catatan Islamic Finance News (IFN) jumlah fintech syariah di Indonesia menduduki urutan keempat setelah Inggris, Malaysia dan Uni Emirat Arat (Inggris Merajai Fintech Syariah Kalahkan Malaysia Dan UEA | Ihram, 2020). Adanya ceruk pasar yang besar turut mendorong perkembangan fintech syariah di Indonesia. Alternatif produk-produk fintech syariah yang memudahkan proses bisnis dan menyelesaikan permasalahan keuangan memberikan tambahan referensi bagi para pelaku usaha (Wijayanti \& Riza, 2017). Selain itu, eksistensi fintech juga sejalan dengan syariah Islam, hal ini karena keberadaan teknologi keuangan mampu menghilangkan leverage (Finocracy \& Mirakhor, 2017; Firmansyah \& Anwar, 2019).

Dibanding dengan lembaga keuangan lainnya, fintech (syariah) memiliki beberapa keunggulan, seperti: kemudahan, kecepatan, dan jangkauan (Mukhlisin, 2019; Prestama et al., 2019). Meskipun demikian, keberadaan fintech tidak luput dari berbagai permasalahan. Dari aspek aturan, regulasi tentang fintech masih sangat minim dibandingkan dengan regulasi lembaga keuangan lainnya (Hiyanti et al., 2020; Prestama et al., 2019; Rusydiana, 2018). Belum lagi dari aspek aturan syariah yang masih memerlukan banyak amademen terhadap aturan-aturannya (Ulya, 2018). Dari aspek sumber daya manusia, ketersediaan SDM untuk mendukung kemajuan fintech syariah juga masih jauh (Hiyanti et al., 2020; Rusydiana, 2018). Dan dari aspek-aspek lainnya seperti: pemahaman masyarakat terhadap fintech syariah (Hiyanti et al., 2020) hingga potensi tindak kejahatan keuangan yang mencoreng nama fintech syariah (Mukhlisin, 2019).

Berkaca pada fenomena di atas, masih diperlukan identifikasi yang lebih komprehensif terhadap kekuatan, kelemahan, peluang dan ancaman (SWOT) fintech syariah dalam mengakselerasi pertumbuhan UMKM di Indonesia. Karena fintech syariah memiliki modal dasar yang kuat dengan segala kelebihannya, salah satunya mendorong pertumbuhan inklusi keuangan. Tulisan ini bertujuan mengkaji peran fintech syariah dalam mempercepat pertumbuhan UMKM di Indonesia.

\section{METODE PENELITIAN}

Berdasarkan jenisnya, penelitian ini menggunakan pendekatan kualitatif yang bersifat eksplorasi guna memahami suatu peristiwa, memastikan kebenaran data, mengkatergorikan data, serta mengkonstuksikan fenomena yang terjadi (Sugiyono, 2019). Sedangkan berdasarkan tujuannya termasuk dalam penelitian deskriptif yang bertujuan memberikan penjelasan mengenai karakteristik pasar atau fungsi (Sekaran \& Bougie, 2016) dalam hal ini adalah fungsi fintech syariah dalam mendorong pertumbuhan UMKM. Jenis data yang digunakan adalah data primer dan sekunder. Sumber data primer diperoleh dari teknik wawancara dengan para pelaku fintech (Investree, Ammana, Efunding dan Igrow) dan AFSI sebagai asosiasi yang mewadahi fintech syariah di Indonesia. Sedangkan data sekunder diperoleh dengan teknik dokumentasi dari berbagai sumber seperti berita (elektronik), jurnal, buletin, working paper, dan dokumen-dokumen lainnya.

Teknik analisis data yang digunakan pada penelitian menggunakan dua pendekatan, yang pertama interactive model dan yang kedua analisis SWOT. Menurut Miles et al. (2013) komponen analisis interactive model terdiri dari reduksi data, penyajian data, penarikan kesimpulan dan verifikasi. Hasil dari interactive model nantinya akan disajikan 
dalam bentuk analisis SWOT yang memuat unsur kekuatan (Strenghts), kelemahan (Weaknesses), peluang (Opportunities), dan ancaman (Threats). Tujuan analisis SWOT dimaksudkan membuat strategi yang tepat bagi fintech syariah dalam rangka mendorong pertumbuhan UMKM di Indonesia dengan berbagai skala prioritas yang ada.

\section{HASIL DAN PEMBAHASAN}

\subsection{Hasil Penelitian}

Sampai dengan Agustus 2020 tercatat sudah ada 157 fintech di Indonesia, dengan total aset 3,12 triliun rupiah. Dari dari jumlah tersebut, 11 diantaranya adalah fintech syariah dengan persentase total aset mencapai 2,04\% (64,97 miliar rupiah) dari total aset fintech secara keseluruhan (OJK, 2020). Jika dilihat dari jumlah penyaluran pembiayaan, secara keseluruhan fintech di Indonesia telah mencapai 121,87 triliun rupiah dengan pertumbuhan $122,74 \%$ per tahun. Angka ini menunjukkan potensi yang sangat besar dari keberadaan fintech di Indonesia, di mana lebih dari $99 \%$ borrower dari fintech adalah UMKM. Jadi tidak diragukan lagi bahwa fintech memiliki peran yang sangat besar dalam mendorong pertumbuhan UMKM di Indonesia. Namun demikian, masih diperlukan upaya-upaya lanjutan untuk mengakselerasikan pertumbuhan UMKM yang diinisiasi oleh fintech syariah.

Dari hasil wawancara dengan semua fintech syariah yang menjadi nara sumber dalam penelitian ini ditemukan bahwa lebih dari 99\% nasabah (borrower) fintech syariah termasuk dalam kategori UMKM yang mana omsetnya tidak ada yang lebih dari 5 miliar rupiah per tahun (kategori usaha menengah menurut UU No. 20 tahun 2008). Segmen pasar ini yang menegaskan bahwa fintech syariah bukan merupakan kompetitor dari perbankan, walaupun ada beberapa segmen pasar fintech syariah yang beririsan dengan segmen pasar bank.

Fakta yang diperoleh dari beberapa hasil wawancara menunjukkan bahwa setelah UMKM menjadi nasabah (borrower) di fintech syariah omsetnya mengalami peningkatan. Salah satu contohnya di Investree Syariah, dimana 54\% nasabahnya mengalami peningkatan omset sampai dengan $30 \%$. Peningkatan omset secara tidak langsung turut meningkatkan pendapatan dan jumlah pegawai. Jika dilihat dari sektor usaha, sektor usaha yang bergerak di bidang manufaktur memiliki dampak pertumbuhan pendapatan sampai dengan 58\% sedangkan sektor usaha keuangan dan real estate merupakan sektor dengan dampak pertumbuhan pendapatan terkecil yaitu $38 \%$. Jika dilihat dari ukuran usaha, temuan yang diperoleh adalah semakin besar ukuran perusahaan (borrower) maka akan semakin besar pula pertumbuhan pendapatannya.

Selain peningkatan pendapatan dan rasio keuangan perusahaan yang terus membaik, UMKM juga mendapat manfaat lain seperti gaining trust dari lembaga keuangan lainnya, salah satunya bank. Pengalaman yang diperoleh sebagai nasabah (borrower) fintech syariah membuat para pelaku usaha (UMKM) naik kelas, karena memiliki pengalaman berhubungan dengan lembaga keuangan. Fintech syariah secara tidak langsung memberikan literasi keuangan kepada para nasabah peminjamnya sehingga mereka mengerti bagaimana caranya berhubungan dengan lembaga keuangan.

Berdasarkan hasil wawancara dengan berbagai nara sumber baik dari para pelaku fintech syariah (Investree, Ammana, Efunding dan Igrow) maupun asosiasi fintech syariah (AFSI) diperoleh hasil analisis SWOT seperti dirangkum pada Tabel 1 di bawah ini.

\section{Tabel 1.}

\section{Analsis SWOT Peran Fintech Syariah dalam} Mendorong Pertumbuhan UMKM di Indonesia

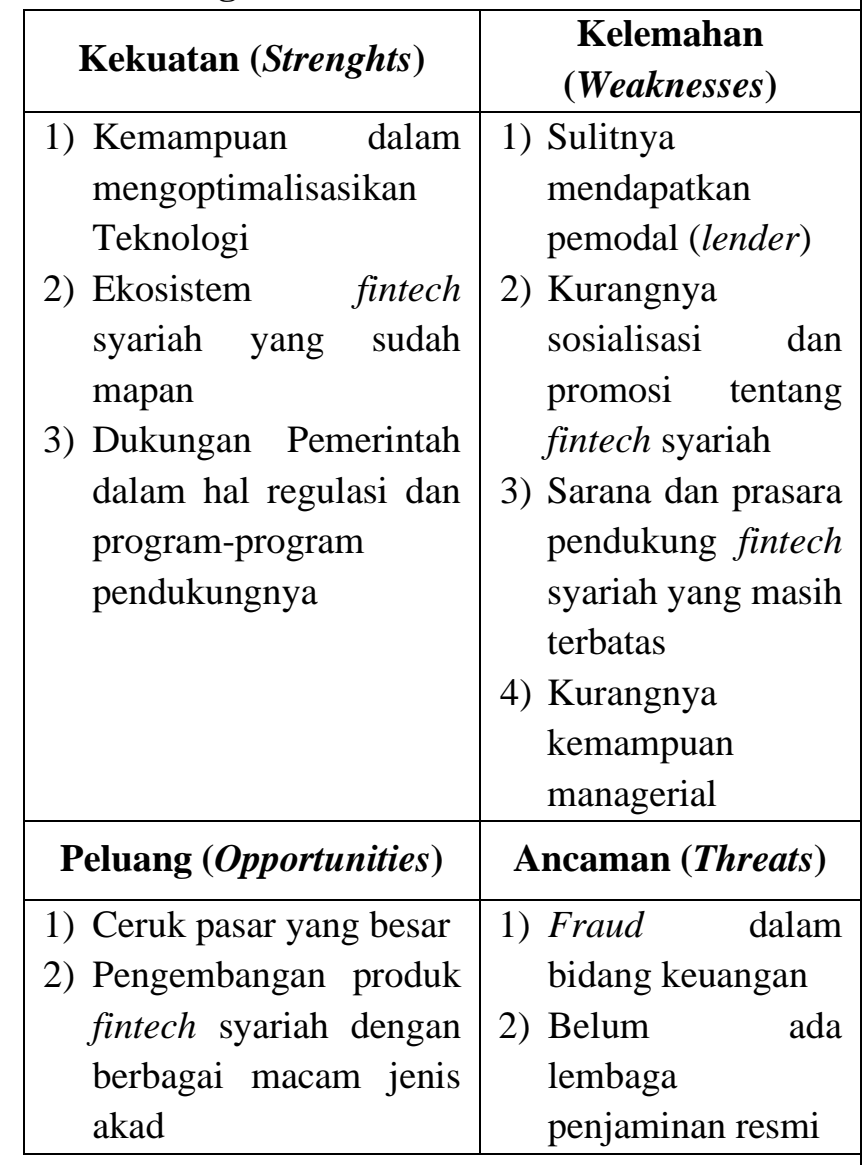


Jurnal Ilmiah Ekonomi Islam, 7(01), 2021, 44

\begin{tabular}{|l|l|}
\hline 3) Belum adanya aturan & 3) Belum ada aturan \\
yang lengkap tentang & yang spesifik dan \\
fintech syariah & menyeluruh \\
& terhadap fintech. \\
& 4) Perizinan \\
& 5) Tingkat \\
& konsumerisme \\
& yang semakin \\
& tinggi \\
& 6) Retail lender \\
\hline
\end{tabular}

Sumber: data diolah (2020)

\section{Kekuatan (Strenghts)}

1) Kemampuan dalam mengoptimalisasikan Teknologi

a. Fintech memiliki kemampuan yang tinggi dalam melakukan digitalisasi layanan jasa keuangan.

b. Fintech memiliki kemampuan big data analysis yang handal. Banyak manfaat yang diperoleh dari kemampuan ini, salah satunya mampu mentransformasikan data dengan sangat cepat. Selain itu, pemanfaatan data tidak hanya sebatas data-data tradisional dalam menganalisis pembiayaan yang akan disalurkan tapi juga menggunakan data-data non tradisional yang sebelumnya tidak dilakukan oleh lembaga keuangan lain seperti bank.

c. Pemanfaatan teknologi juga berdampak pada tingginya aksesibilitas fintech, mulai dari tersedianya website, sampai aplikasi pada mobile phone. Aksesibilitas ini juga memberikan kemudahan kepada calon nasabah untuk mendapatkan informasi yang akurat, cepat, dan terinci.

d. Keberadaan teknologi yang menjadi dasar eksistensi fintech selain memberikan kecepatan juga memberikan keamanan dalam bertransaksi. Teknologi membuat para lender merasa aman dalam menitipkan dananya. Selain itu, hal ini juga membuat para borrower mendapatkan pelayanan yang cepat dalam mendapatkan pinjaman. Mulai dari persetujuannya cepat, hingga proses registrasi yang mudah.

e. Dampak yang tidak kalah penting dari kehandalan teknologi di fintech adalah terciptanya jangkauan yang luas. Tanpa harus memiliki cabang disetiap daerah, fintech dapat menjaring mitra dalam menyalurkan pembiayaan. Mitra fintech di daerah dapat berupa lembaga keuangan maupun agen lapangan yang berguna dalam menjangkau daerah-daerah yang sulit dijangkau.

2) Ekosistem fintech syariah yang sudah mapan

a. Kemampuan teknologi memudahkan ekosistem dalam fintech untuk berintegrasi, baik itu pemerintah, pelaku usaha, maupun konsumen. Jalinan kerjasama antar lembaga turut menumbuhkan kepercayaan di masyarakat akan eksistensi fintech syariah yang pada akhirnya turut menaikan kredibilitasnya.

b. Kerjasama fintech syariah dengan bank syariah dalam menyalurkan pembiayaan merupakan simbiosis mutualisme. Fintech mendapatkan pendanaan, sedangkan Bank terbantu dalam hal penyaluran pembiayaan, karena keberadaan fintech dapat meminimalisir biaya, waktu dan tenaga.

c. Kerjasama dengan para pelaku usaha, seperti e-commerce/marketplace dan perusahaan-perusahan multinasional memudahkan fintech syariah menjangkau UMKM guna menyalurkan pembiayaannya. Kemudahan akses data atas kolaborasi ini, membuat kerja fintech menjadi lebih efisien dan terbentuk ekosistem yang lebih luas lagi. Pada akhirnya, hal ini akan memudahkan fintech dalam menjaungkau borrower yang berkualitas.

d. Adanya kolaborasi dengan berbagai stakeholder fintech syariah juga merupakan bagian dari mitigasi risiko. Sebagai contoh, nasabah yang diperoleh dari mitra jauh lebih dipercaya dibandingkan nasabah yang tanpa mitra. Kolaborasi dipercaya dapat meminimalisir risiko.

3) Dukungan Pemerintah dalam hal regulasi dan program-program pendukungnya.

a. Walau relatif baru, adanya aturan yang memanyungi keberadaan fintech syariah dari segi bentuk usaha, model bisnis sampai dengan operasionalisasinya dapat memberikan rasa aman stakeholder fintech syariah.

b. Peran pemerintah dalam mendukung pertumbuhan fintech syariah cukup baik, 
sudah ada bagian tersendiri yang memudahkan perizinan fintech (syariah). Selain itu kerjasama dengan Asosiasi Fintech Syariah Indonesia (AFSI) yang juga menjadi perpanjangan tangan pemerintah (OJK) dalam hal pengawasan turut memberikan kontribusi yang besar.

\section{Kelemahan (Weaknesses)}

1) Sulitnya mendapatkan pemodal (lender)

Sebagian besar fintech syariah mengalami over demand, kondisi dimana lebih banyaknya borrower dibandingkan lender. Kurangnya pemodal yang bergabung dalam fintech syariah menyebabkan pembiayaan yang dapat disalurkan kepada borrower terbatas. Sehingga antrian pada borrower relatif tinggi. Dampak yang ditimbulkan dari kejadian ini adalah tingkat kepercayaan borrower terhadap fintech syariah yang semakin berkurang. Hal yang sebaliknya juga dapat terjadi, yaitu over supply. Kondisi ini juga dapat menurunkan kepercayaan lender kepada fintech syariah.

2) Kurangnya sosialisasi dan promosi tentang fintech syariah

a. Perusahaan fintech memiliki tanggung jawab khusus yang diberikan oleh regulator dalam rangka meningkatkan literasi dan inklusi keuangan. Namun kurangnya sumber daya yang dimiliki membuat usaha ini belum dapat dilakukan secara optimal.

b. Tingkat literasi keuangan syariah relatif masih sangat kecil dikalangan UMKM. Sebagaimana hasil survei yang dilakukan oleh OJK pada tahun 2019, bahwa tingkat literasi keuangan syariah baru mencapai $8,93 \%$.

3) Sarana dan prasara pendukung fintech syariah yang masih terbatas

a. Masih sedikitnya bank syariah sebagai mitra bagi fintech syariah (aturan OJK) dalam segi jumlah maupun ukuran (size) bank syariahnya. Akibatnya infrastruktur di bank syariah belum seperti bank konvensional, seperti aksesibilitas dan fitur keuangan digital.

b. Selain itu, perangkat pendukung lainnya juga belum dimiliki oleh fintech syariah seperti DPS (Dewan Pengawas Syariah).
4) Kurangnya kemampuan managerial

Salah satu bukti lemahnya kemampuan managerial pengelola fintech syariah adalah lemahnya kordinasi dengan para mitra di daerah, sehingga sering kali terjadi kelambatan proses validasi calon nasabah (borrower) yang pada akhirnya menurunkan kepercayaan mitra-mitra yang ada.

\section{Peluang (Opportunities)}

1) Ceruk pasar yang besar

a. Ceruk pasar fintech adalah UMKM, yang mana merupakan penyumbang terbesar terhadap PDB Indonesia (mencapai 54\%). Dari sisi jumlah pelaku usaha, UMKM memiliki persentase hingga 97\% dari total pelaku usaha di Indonesia. Ditambah animo masyarakat yang sedang meningkat karena faktor sosio-ekonomi dan politik di Indonesia.

b. Ceruk pasar ini juga ditunjukkan oleh tingginya pengguna aplikasi berbasis teknologi di Indonesia. Penetrasi ponsel pintar (smartphone) di indoensia tumbuh 25,9\% dalam enam tahun terakhir (20142019). Diperkirakan jumlah pemakai ponsel pintar pada tahun 2025 akan mencapai 89,2\% dari total penduduk Indonesia.

2) Pengembangan produk fintech syariah dengan berbagai macam jenis akad

Dalam syariah Islam dikenal berbagai macam akad pada berbagai sektor ekonomi, seperti akad zakat, wakaf, qardhul hasan yang sifatnya non komersil hingga akad yang bersifat komersil seperti murabahah, ijarah, mudharabah hingga musyarakah. Keberagaman ini memberikan peluang tersendiri dalam penembangan produk di fintech syariah.

3) Ruang aturan tentang fintech syariah yang masih terbuka luas

a. Belum ada aturan-aturan yang mengikat, memungkinkan fintech melakukan manuver untuk melakukan pengembangan terhadap teknologi finansial guna mendukung pelayanan kepada nasabah, terutama nasabah borrower.

b. Pengembangan aturan yang ada dapat diinisiasi oleh para pelaku fintech lewat asosiasi. Hal ini tentunya memberikan ruang yang luas bagi para pelaku fintech syariah dalam merancang aturan kedepannya. 


\section{Ancaman (Threats)}

1) Fraud dalam bidang keuangan

Munculnya fintech ikut memunculkan berbagai modus baru dalam tindak pidana bidang keuangan. selain itu, keberadaan fintech ilegal juga ikut mencoreng nama baik fintech legal. Praktek-praktek yang dilakukan oleh fintech ilegal tidak sesuai dengan aturan-aturan yang berlaku.

2) Belum ada lembaga penjaminan resmi

Tidak seperti bank yang memiliki Lembaga Penjamin Simpanan (LPS), fintech tidak memiliki lembaga penjaminan guna mencover kerugian atas dana para lender. Hal ini tentunya mengurangi kepercayaan masyarakat untuk menginvestasikan dananya di fintech yang pada akhirnya menjadi hambatan bagi penyediaan dana untuk pembiayaan di sektor UMKM.

3) Belum ada aturan yang spesifik dan menyeluruh terhadap fintech.

Aturan yang belum jelas selain menjadi potensi, juga dapat menjadi ancaman tersendiri. Pada saat aturan yang dibentuk tidak berpihak kepada pelaku usaha fintech, maka itu akan menjadi ancaman yang serius bagi industri fintech.

4) Perizinan

Belum semua perusahaan fintech syariah memiliki izin dari OJK. Pada saat izin belum diterbitkan, tentunya akan menjadi ancaman atas perusahaan fintech syariah tersebut.

5) Tingkat konsumerisme yang semakin tinggi Kendala dari sisi UMKM yang sering ditemui adalah mindset sebagian pelaku UMKM yang salah, dimana masih menganggap bahwa dengan fintech skemanya adalah dipinjamkan uang.

6) Retail lender

Mengurus retail lender jauh lebih sulit dibandingkan corporate lender. Padahal jumlah retail lender di fintech syariah jumlahnya cukup banyak. Melakukan restrukturisasi untuk retail lender pada saat terjadi krisis finansial (seperti pandemi COVID-19), jauh lebih sulit karena cadangan yang mereka miliki jauh lebih kecil dibandingkan corporate lender. Berbeda dengan borrower yang secara sistem lebih terukur dan terkontrol.

\subsection{Pembahasan}

Keberadaan fintech syariah di Indonesia memiliki banyak kelebihan dan kekuatan, tetapi faktor utama menjadi pendorong pertumbuhan UMKM di Indonesia dikelompokkan ke dalam tiga kekuatan utama. Pertama, kemampuan fintech syariah dalam mengoptimalisasikan teknologi yang dimiliki. Hal ini dikuatkan oleh temuan (Hiyanti et al., 2020; Prestama et al., 2019; Rusydiana, 2018). Kemajuan teknologi mampu mengurangi waktu tunggu, lalu lintas jalan dan antrian transaksi (Mukhlisin, 2019). Sudah menjadi sunatullah keberadaan teknologi akan membuat segala proses menjadi cepat, mudah dan singkat. Keunggulan inilah yang dipercaya menjadi modal masa depan fintech untuk terus berkembang menjadi lebih besar lagi yang pada akhirnya akan berdampak pada pertumbuhan UMKM itu sendiri. Minerva (2016) mengungkapkan bahwa salah satu faktor kunci fintech dapat mendukung pertumbuhan UMKM adalah tingkat penggunaan teknologi digital oleh UMKM.

Kekuatan kedua dari fintech syariah adalah memiliki ekosistem yang relatif mapan. Didukung oleh kekuatan teknologi, kekuatan ekosistem dalam prosesnya menjadi semakin kuat dan luas. Kolaborasi dan sinergi fintech syariah dengan pelaku usaha, pemerintah dan akademisi dalam suatu ekosistem yang mapan dan dukungan teknologi yang memadai diyakini akan mendorong pertumbuhan fintech syariah (Haris et al., 2020; Rusydiana, 2018). Kekuatan ketiga yang tidak kalah penting adalah dukungan Pemerintah. Tidak dapat dielakkan bahwa besar kecilnya sebuah industri ada peran pemerintah di dalamnya. Keberpihakan pemerintah dalam hal regulasi menjadi landasan yang kuat untuk fintech syariah mendorong penyaluran pembiayaan ke UMKM (Minerva, 2016). Kebijakan yang dibuat pemerintah dalam mendorong literasi dan inklusi keuangan serta program-program pendukung lainnya secara tidak langsung dapat mengakselerasikan peran fintech menumbuhkan UMKM di Indonesia.

Selain kekuatan yang dimiliki, ada beberapa kelemahan yang teridetifikasi. Sulitnya fintech syariah mendapatkan pemodal (lender) ternyata masih menjadi permasalah klasik fintech. Bisnis model yang ada di fintech tidak serta merta memudahkan fintech mendapatkan pemodal. Selain itu, tidak seperti bank yang memiliki lembaga penjamin simpanan, fintech belum memiliki lembaga penjaminan bagi para lender. Permasalah klasik kedua adalah sosialisasi dan promosi. Temuan ini juga dikuatkan oleh penelitianpenelitian sebelumnya, terkait rendahnya tingkat literasi dan inklusi masyarakat akan lembaga 
keuangan syaiah, terlebih fintech syariah (Hiyanti et al., 2020; Minerva, 2016; Muzdalifa et al., 2018; Prestama et al., 2019), di mana salah satu penyebabnya kurang sosialisasi dan promosi. Kelemahan ketiga yang ditemui adalah keterbatasan sarana dan prasara pendukung fintech syariah. Seperti yang ditemukan oleh Muzdalifa et al. (2018), bahwa perkembangan fintech syariah masih terkendala dengan permasalahan infrastruktur. Kelemahan terakhir yang sering ditemui disetiap entitas bisnis yang baru berkembang adalah rendahnya kemampuan managerial. Hal ini diperparah dengan kurangnya sumber daya manusia yang menguasai akad transaksi berdasarkan prinsip syariah (Hiyanti et al., 2020).

Setelah identifikasi kekuatan dan kelemahan fintech syariah dalam mempercepat pertumbuhan UMKM di Indonesia, pembahasan selanjutnya adalah tentang peluang yang dimiliki oleh fintech syariah. Setidaknya ditemukan tiga peluang utama, yaitu: ceruk pasar yang besar, pengembangan produk fintech syariah dengan berbagai macam jenis akad, serta belum adanya aturan yang lengkap tentang fintech syariah. Besarnya ceruk pasar pembiayaan UMKM menjadi peluang utama yang secara otomatis menjadi keuntungan tersendiri bagi industri fintech syariah. Di saat lembaga keuangan lainnya kesulitan mencari nasabah pembiayaan, fintech mendapatkan kesempatan itu. Hal ini dikuatkan oleh penelitian Haris et al. (2020) yang menyatakan bahwa pangsa pasar pembiayaan UMKM secara keseluruhan masih belum digarap. Indonesia yang mayoritas beragama Islam (Hiyanti et al., 2020) seharusnya menjadi peluang yang sangat besar bagi perkembangan fintech syariah dalam mendorong pertumbuhan UMKM di Indonesia. Dari sisi aturan, peluang fintech untuk mendapatkan legalitas dari pemerintah (OJK) jauh lebih tinggi dibandingkan lembaga keuangan lainnya (Hiyanti et al., 2020). Keuntungan ini tentunya tidak akan didapatkan di kemudian hari pada saat jumlah fintech sudah sangat banyak sepertin jumlah bank saat ini. Ke depannya pemerintah tentunya akan membuat aturan yang lebih ketat dalam memberikan perizinan terhadap fintech.

Tantangan yang dihadapi oleh fintech syariah dimulai dari tindak pidana pada bidang keuangan. Hasil ini dikuatkan oleh temuan Mukhlisin (2019) yang menyatakan bahwa keberadaan fintek meningkatkan tindak kejahatan digital. Selain itu, seperti yang sudah dibahas pada bagian kelemahan, tentang prasarana pendukung fintech yaitu belum adanya lembaga penjaminan resmi. Hal ini menjadi ancaman serius terkait risiko yang ditanggung oleh para lender. Terkait belum adanya aturan yang spesifik dan menyeluruh terhadap fintech selain menjadi berkah untuk proses pengembangan, di sisi lain dapat menjadi ancaman. Karena bukan tidak mungkin aturan-aturan yang ada ke depannya dapat menghambat peran fintech syariah. Ancaman lain yang tidak dapat dikesampingkan dari keberadaan fintech adalah berkurangnya tenaga kerja dalam bidang keuangan. Peningkatan angka pengangguran telah dibuktikan dengan survei LinkedIn yang menyimpulkan 25 persen profesi keuangan khawatir kehilangan pekerjaan karena banyak bidang telah diubah menjadi otomatisasi (Weissbluth, 2017).

Melihat banyaknya komponen dari setiap bagian dalam bagan analisis SWOT, maka rumusan terhadap strategi yang ditawarkan coba lebih disederhanakan. Berdasarkan kekuatan (strenghts) dan peluang (opportunities) yang dimiliki oleh fintech syariah, setidaknya ada beberapa strategi yang dapat ditawarkan. Pertama, dengan cara menguatkan ekosistem dan dukungan regulasi. Di antara fintech syariah, UMKM selaku borrower, perbankan syariah dan investor selaku lender, serta pemerintah selaku regulator harus terbina sinergi yang baik. Demikian pula, untuk jangka panjang peranan akademisi harus dilibatkan untuk membangun ekosistem fintech syariah yang berkesinambungan, sehingga tercipta bentuk sinergi dalam bentuk quadrupal helix, dengan fintech syariah selaku industri, UMKM dan investor selaku civil society, serta pemerintah selaku regulator dan perguruan tinggi dengan akademisinya yang berperan sesuai dengan tugasnya demi membangun ekosistem yang baik bagi pertumbuhan fintech syariah di Indonesia. Kedua, optimalisasi segala potensi yang terdapat dalam kekuatan dan peluang yang ada, baik optimalisasi dalam kemampuan teknologi, maupun pengembangan akad-akad serta membangun pasar, baik untuk borrower maupun lender.

Sedangkan jika dilihat dari sisi kekuatan (strenghts) dan ancaman (threats) strategi-strategi yang dapat dilakukan antara lain: pertama, mengupayakan dukungan dari pemerintah dari sisi regulasi agar terdapat aturan yang lebih spesifik dan menyeluruh yang mendukung pengembangan fintech pada umumnya, dan fintech syariah pada khususnya, diharapkan aturan tersebut juga mencakup tentang kemudahan mendapatkan izin operasional bagi fintech syariah, sehingga keberadaannya dapat lebih mudah 
diawasi. Dengan banyaknya fintech Syariah yang keberadaannya dapat diawasi oleh otoritas akan mencegah tindakan fraud seperti yang sering terjadi selama ini akibat tidak adanya pengawasan. Kedua, melakukan sosialisasi kepada masyarakat terkait dengan pentingnya memilih fintech Syariah yang mempunyai izin, serta manfaat fintech yang dapat dioptimalkan untuk membangun UMKM, diharapkan dengan demikian masyarakat dapat meninggalkan sifat konsumerisme dan beralih ke pinjaman-pinjaman produktif.

Melihat kelemahan (weaknesses) dan peluang (opportunities), sebaiknya dilakukan strategi-strategi sebagai berikut: pertama, peningkatan kemampuan manajerial fintech syariah, khususnya dengan cara mengatur agar terdapat mitra yang tersebar di daerahdaerah untuk validasi calon nasabah. Cara seperti ini bukan berarti bahwa masing-masing fintech syariah harus menempatkan masing-masing mitra di daerah, tapi dapat dilakukan dengan kolaborasi antar fintech syariah, sehingga mitra tidak hanya menjalankan validasi untuk satu fintech syariah saja, tetapi seluruh fintech syariah yang tergabung dalam asosiasi. Kegiatan ini juga dapat dilakukan dengan melakukan kolaborasi dengan lembaga keuangan daerah seperti koperasi atau BMT untuk menjadi agen. Dengan kebutuhan nasabah yang terlayani dengan baik maka ceruk pasar yang sudah besar tersebut dapat dioptimalkan sehingga meningkatkan kapasitas fintech syariah. Imbas dari meningkatnya kapasitas fintech syariah adalah kepercayaan yang semakin tinggi, sehingga pemodal (lender) percaya untuk menitipkan dananya kepada fintech syariah karena yakin akan adanya pengembalian yang menjanjikan. Kedua, seiring dengan kepercayaan yang meningkat, perlu juga digencarkan promosi tentang fintech yang menawarkan skema syariah, di mana skema syariah memungkinkan untuk dikembangkan dalam berbagai macam akad sesuai dengan kebutuhan nasabahnya.

Sedangkan jika dilihat dari kelemahan (weaknesses) dan ancaman (threats) yang ada, maka sebaiknya fintech syariah melakukan pendekatan khusus kepada bank-bank syariah agar tercipta hubungan yang saling mendukung antara kedua industri ini, di mana fintech syariah membutuhkan bank syariah untuk penempatan dana, sehingga terdapat corporate lender yang akan mensuplai dana bagi kebutuhan pembiayaan dengan permintaan yang tinggi dari para nasabahnya. Sedangkan, bank syariah juga sebaiknya bersinergi dengan fintech syariah, sebab fintech syariah memiliki kemampuan pengelolaan dana yang baik, sehingga dapat menghasilkan imbal hasil yang menarik yang tentunya dapat menguntungkan bank syariah.

Tabel 2.

Strategi Fintech Syariah dalam Mendorong Pertumbuhan UMKM di Indonesia

\begin{tabular}{|c|c|c|}
\hline & $\begin{array}{c}\text { Kekuatan } \\
\text { (Strenghts) }\end{array}$ & $\begin{array}{c}\text { Kelemahan } \\
\text { (Weaknesses) }\end{array}$ \\
\hline $\begin{array}{l}\text { Peluang } \\
\text { (Opportun } \\
\text { ities) }\end{array}$ & $\begin{array}{l}\text { 1. Penguatan } \\
\text { ekosistem } \\
\text { dengan sinergi } \\
\text { antara industri - } \\
\text { pemerintah - } \\
\text { akademisi - } \\
\text { masyarakat } \\
\text { 2. Optimalisasi } \\
\text { potensi, } \\
\text { pengembangan } \\
\text { akad dan pasar }\end{array}$ & $\begin{array}{l}\text { 1. Peningkatan } \\
\text { kemampuan } \\
\text { manajerial } \\
\text { fintech syariah } \\
\text { dengan } \\
\text { memanfaatkan } \\
\text { BMT dan } \\
\text { koperasi } \\
\text { Syariah daerah } \\
\text { 2. Promosi } \\
\text { fintech dengan } \\
\text { aneka akad } \\
\text { sesuai } \\
\text { kebutuhan } \\
\text { UMKM }\end{array}$ \\
\hline $\begin{array}{l}\text { Ancaman } \\
\text { (Threats) }\end{array}$ & $\begin{array}{l}\text { 1. Dukungan } \\
\text { regulasi untuk } \\
\text { penguatan } \\
\text { fintech syariah } \\
\text { 2. Sosialisasi } \\
\text { pentingnya } \\
\text { memilih fintech } \\
\text { syariah berizin } \\
\text { dan pentingnya } \\
\text { pembiayaan } \\
\text { produktif }\end{array}$ & $\begin{array}{l}\text { Pendekatan } \\
\text { khusus kepada } \\
\text { bank syariah } \\
\text { selaku corporate } \\
\text { lender dengan } \\
\text { potensi sinergi } \\
\text { yang saling } \\
\text { menguntungkan. }\end{array}$ \\
\hline
\end{tabular}

Sumber: data diolah (2020)

\section{KESIMPULAN}

Selain memberikan pendanaan yang lebih mudah dijangkau oleh masyarakat, keberadaan fintech syariah juga mendorong pengembangan sektor-sektor produktif yang saat ini tidak terlayani oleh layanan perbankan. Kendala pengembangan fintech syariah dalam mendorong pertumbuhan UMKM di Indonesia setidaknya dapat diselesaikan dengan tiga strategi. Pertama, penguatan ekosistem berupa sinergi antara fintech syariah, pengguna jasa fintech (borrower) dan perbankan syariah (lender) selaku civil society, pemerintah yang merupakan regulator dan kalangan perguruan tinggi selaku akademisi. Kedua, 
mengoptimalkan potensi yang ada pada fintech syariah, seperti meningkatkan kemampuan manajerial dan pemahaman terhadap akad-akad syariah sehingga mampu menghasilkan produk-produk fintech syariah sesuai kebutuhan UMKM. Ketiga, menggali ceruk pasar yang telah tersedia dengan sosialisasi dan promosi yang masif serta terarah.

\section{UCAPAN TERIMA KASIH}

Ucapan terima kasih kami sampaikan kepada Kementrian Riset, Teknologi dan Pendidikan Tinggi (ristekdikti) yang telah mendanai penelitian ini. Selain itu, kami juga sampaikan terima kasih kepada Perbanas Institute yang telah mewadahi kami dalam menyelesaikan penelitian ini.

\section{REFERENSI}

BI. (2017). PBI NOMOR 19/12/PBI/2017 tentang Penyelenggaraan Teknologi Finansial. Bank Indonesia.

Buckley, R., Arner, D., \& Barberis, J. (2016). 150 Years of FinTech: An Evolutionary Analysis. JASSA - The FINSIA Journal of Applied Finance, 3, 22-29.

Demirgüç-Kunt, A., Beck, T., \& Honohan, P. (2008). Finance for All? Policies and Pitfalls in Expanding Access. A World Bank Policy Research Report.

DSN-MUI. (2018). Fatwa Dewan Syariah NasionalMajelis Ulama Indonesia No: 117/DSNMUI/II/2018 tentang Layanan Pembiayaan Berbasis Teknologi Informasi Berdasarkan Prinsip Syariah.

Finocracy, A. A., \& Mirakhor, A. (2017). Accelerating Risk Sharing Finance via FinTech: NextGen Islamic Finance. 10.

Firmansyah, E. A., \& Anwar, M. (2019). Islamic Financial Technology (Fintech): Its Challenges and Prospect. 52-58.

Haris, M., Iqbal, M., \& Hadiyati, P. (2020). Synergy of Sharia Banks and Financial Technology in The Development of Micro, Small and Medium Businesses in Indonesia. Jurnal Reviu Akuntansi Dan Keuangan, 10(1), 115-126.

Hiyanti, H., Nugroho, L., Sukmadilaga, C., \& Fitrijanti, T. (2020). Peluang dan Tantangan Fintech (Financial Technology) Syariah di Indonesia. Jurnal Ilmiah Ekonomi Islam, 5(3), 326-333.
Indika, M., \& Marliza, Y. (2019). Upaya Upaya Pemberdayaan Usaha Mikro Kecil Menengah (UMKM) Dalam Mengatasi Kemiskinan di Kecamatan Tugumulyo Kabupaten Musi Rawas. Journal Management, Business, and Accounting, 18(3), 49-66.

Inggris Merajai Fintech Syariah Kalahkan Malaysia dan UEA | Ihram. (2020, August 6). Ihram.Co.Id. https://ihram.co.id/berita/qemu8x366/inggrismerajai-fintech-syariah-kalahkan-malaysia-danuea

Krisnawati, K. (2016). Upaya Penanggulangan Kemiskinan Melalui Pemberdayaan Usaha Mikro Kecil Dan Menengah. Sosio Informa, 2(2), 137154.

Leong, K., \& Sung, A. (2018). FinTech (Financial Technology): What is It and How to Use Technologies to Create Business Value in Fintech Way? International Journal of Innovation, Management and Technology, 9(2), 74-78.

Maier, E. (2016). Supply and demand on crowdlending platforms: Connecting small and medium-sized enterprise borrowers and consumer investors. Journal of Retailing and Consumer Services, 33(6), 143-153.

Miles, M. B., Huberman, A. M., \& Saldaña, J. (2013). Qualitative Data Analysis: A Methods Sourcebook (3rd Edition). SAGE Publications, Inc.

Minerva, R. (2016). The potential of the Fintech industry to support the growth of SMEs in Indonesia. Management Strategy and Industry Evolution.

Mukhlisin, M. (2019). Islamic Fintech: Quo Vadis? Insight: Buletin Ekonomi Islam, V, 17-18.

Muzdalifa, I., Rahma, I. A., \& Novalia, B. G. (2018). Peran Fintech Dalam Meningkatkan Keuangan Inklusif Pada UMKM Di Indonesia (Pendekatan Keuangan Syariah). Jurnal Masharif al-Syariah: Jurnal Ekonomi dan Perbankan Syariah, 3(1), Article 1.

OJK. (2020). Perkembangan Fintek Lending. Otoritas Jasa Keuangan.

Prestama, F. B., Iqbal, M., \& Riyadi, S. (2019). Potensi Finansial Teknologi Syariah dalam Menjangkau Pembiayaan Non-Bank. Al-Masraf: Jurnal Lembaga Keuangan dan Perbankan, 4(2), 147-158. 


\section{Jurnal Ilmiah Ekonomi Islam, 7(01), 2021, 50}

Rusydiana, A. S. (2018). Bagaimana Mengembangkan Industri Fintech Syariah di Indonesia? Pendekatan Interpretive Structural Model (ISM). AL-MUZARA'AH, 6(2), 117-128.

Sarfiah, S. N., Atmaja, H. E., \& Verawati, D. M. (2019). UMKM Sebagai Pilar Membangun Ekonomi Bangsa. Jurnal REP (Riset Ekonomi Pembangunan), 4(2), 137-146.

Schueffel, P. mname. (2016). Taming the Beast: A Scientific Definition of Fintech. Journal of Innovation Management, 4(4), 32-54.

Sekaran, U., \& Bougie, R. (2016). Research Methods For Business: A Skill Building Approach (7th Edition). Wiley.

Setiawan, R. D. (2017). Peran UMKM Dalam Upaya Pemberantasan Pengangguran dan Kemiskinan: Pelajaran Dari Penerapan JATIMNOMICs Di Blitar. Jurnal Ilmiah Mahasiswa FEB, 5(2), 118.

Sugiyono. (2019). Metode Penelitian Kuantitatif, Kualitatif, dan $R \& D$ (1st ed.). Alfabeta. http://cvalfabeta.com/product/metodepenelitian-kuantitatif-kualitatif-dan-rd-mpkk/
Tambunan, T. T. H. (2012). Peran Usaha Mikro dan Kecil dalam Pengentasan Kemiskinan di Daerah. Jurnal Bina Praja: Journal of Home Affairs Governance, 4(2), 73-92.

Ulya, N. U. (2018). Peer to Peer Lending on Financial Technology Under Perspective Positive Law And Islamic Law. Journal of Islamic Business Law, 2(1), Article 1.

Wijayanti, D. M., \& Riza, A. F. (2017, September 6). Sharia Fintech: Positive Innovation in Consumer Perspective. Proceeding. International Seminar Academic Network on Competition Policy, Bali. Wulandari, P. A. (2017). Analisis SWOT Perkembangan Finansial Teknologi di Indonesia. Proceeding of National Conference on Asbis, 2, 376-383.

Zetzsche, D. A., Buckley, R. P., Arner, D. W., \& Barberis, J. N. (2018). From FinTech to TechFin: The Regulatory Challenges of Data-Driven Finance (No. 6; pp. 1-41). European Banking Institute. 